\title{
New Utilities for Cancer Treatment to Inhibit Tubulin Assembly and Suppressing Microtubule Formation: Research Hypothesis
}

\author{
Divya Shastri ${ }^{1}$ and Vinit Raj ${ }^{2 *}$ \\ ${ }^{1}$ Department of Pharmacy, Central University of Rajasthan, India \\ ${ }^{2}$ Department of Pharmaceutical sciences, Babasaheb Bhimrao Ambedkar University, India
}

Submission: September 21, 2018; Published: September 27, 2018

*Corresponding author: Vinit Raj, Department of Pharmaceutical sciences, Babasaheb Bhimrao Ambedkar University, Lucknow, Uttar Pradesh, India, Email: raj.vinit24@gmail.com

Abstract

The main objective of present research hypothesis was to give the idea and taking the attention of researcher for tubulin as an anticancer drug target. Inhibiting tubulin by novel lead scaffold may be helpful to treat the cancer with reduced side effect and higher selectivity toward the cancer cells. The present problems with cancer drug have cancer cell resistant and adverse effects. Assisting the solution of this problem, we hypothesized; Pharmacophore based selection for new scaffold may exhibit better binding affinity and selectivity towards the tubulin assembly and suppressing microtubule formation and attenuating the adverse effects and resistant of drug molecules.

Keywords: Novel Lead Scaffold; Tubulin/Microtubule Inhibitor; Pharmacophore; QSAR

\section{Introduction}

Cancer is one of the most widespread health diseases and causes high cancer-related mortality in both developing and developed countries. The clinical outcome of cancer treatment is remains limited due to severe adverse effects and tumor resistance towards marketed chemotherapeutic drugs. To address these problems, we hypothesized that, inhibiting tubulin assembly and suppressing microtubule formation in the cancerous cell as target-based selectivity and novel molecule discovery may be assessing this life threading disease. There are maximum drug molecules that interrupt microtubule/tubulin dynamics are most conventionally used in cancer treatment. tubulin, an $\alpha, \beta$-heterodimer protein Binding that forms the core of microtubule. Antimitotic agents (microtubule targeting agents (MTA)), arrest the cells only only mitosis but also cell interphase [1-2]. MTAs have the tubulin binding via at least four binding sites: taxane/epothilone, the laulimalide, colchicine and vinca alkaloid sites. Similar to Laulimalide, paclitaxel can encourage the tubulin-microtubule assembly, but the binds to a different site on the microtubules. Taxanes, including docetaxel and paclitaxel, bind to polymerized microtubules at inner surface of $\beta$ subunit, and are extensively used in the treatment of breast, lung bladder, and ovarian cancers. Taxanes interfere with tubulin dynamics and promote tubulin stabilization [3]. Vinca alkaloids such as vinblastine, vincristine, vinorelbine and promote microtubules depolymerization. They conventionally exhibit higher affinity to one or a few tubulin molecules at the chain of microtubules but do not be copolymerize into microtubules. Colchicine, showing interfering in the microtubule and also induces depolymerization of microtubule. Colchicine usally binds to $\beta$-tubulin and its results in curved dimer of tubulin and prevents it to adopt a straight structure, by a steric clash between $\alpha$-tubulin and colchicine, which inhibits microtubule assembly [4-6].

\section{Research Envisaged}

Privileged literature suggested that for inhibiting tubulin assembly and suppressing microtubule formation is exhibited better selectivity for the treatment of cancer by the lead drug molecules. The Colchicines and Taxanes derivatives have the potent inhibition properties towards tubulin. Keep in mind pharmacophore and structure activity relationship (SAR) pattern of privileged of these compounds, we hypothesized that structure based similar compound which will have the better binding towards the above cited targets may be better drug molecules for the cancer treatment. We would try to discover novel scaffold on the basis of Pharmacophoric patterns of privileged drug and explore their possible inhibiting tubulin assembly and suppressing microtubule formation underling mechanism of action for the treatment.

\section{Objectives of the Work}

The purpose of this study is to discover of potent scaffold as inhibitor tubulin assembly and suppressing microtubule formation in cancerous cells. The main objectives is to 
a) Discover potent scaffold against tubulin assembly and suppressing microtubule formation

b) In vitro effectiveness against specific cancer cell line.

c) Perform the acute toxicity for finding safe dose regimen.

d) Perform the pharmacokinetic study for finding the absorption profile of compounds.

e) Perform in vivo study using chemical or tumor xenograft induced model in albino Wistar rats.

f) Explore the underling molecular pathways of discover scaffold.

g) Measure the metabolic perturbations through $1 \mathrm{H}-\mathrm{NMR}$ in cancerous treated rats.

\section{Methodology and Plan of Work}

Following methodology would be used for completing proposed objectives

a) Discovery of novel compounds as inhibitor tubulin assembly and suppressing microtubule formation by using Bioinformatics study e.g. molecular Docking etc.

b) Evaluated the potency against human cancer cells by using SRB or MTT assay.

c) Acute animal toxicity and Pharmacokinetic studies would be performed according OECD guidelines and liquidliquid extraction, respectively. d) In vivo study using chemical or tumor xenograft induced model in albino Wistar rats as well as NMR based metabolomic study as per previously reported protocol.

\section{Conclusion}

The conclusion of this hypothesis may be better plate form to exploring the research idea towards the tubulin as potent target for the treatment of cancer. The privileged drug molecule has the tumor resistant as well as adverse effect for the normal cell. To address the answer of these problems, new scaffolds are the better idea to reduce the adverse effects and improve the selectivity of compound toward the cancer cell.

\section{References}

1. Lopez-Fanarraga M, Avila J, Guasch A, Coll M, Zabala JC (2001) Review: postchaperonin tubulin folding cofactors and their role in microtubule dynamics. J Struct Biol 135: 219-229.

2. Hall A (2009) The cytoskeleton and cancer. Cancer Metastasis Rev 28: $5-14$.

3. Jordan MA, Wilson L (2004) Microtubules as a target for anticancer drugs. Nat Rev Cancer 4: 253-265.

4. Risinger AL, Giles FJ, Mooberry SL (2009) Microtubule dynamics as a target in oncology. Cancer Treat Rev 35: 255-261.

5. Riham I Ahmeda, Essam Eldin A Osmanb, Fadi M Awadallahb, Samir M El-Moghazyb (2017) Design, synthesis and molecular docking of novel diarylcyclohexenone and diarylindazole derivatives as tubulin polymerization inhibitors. J Enzyme Inhibition Med Chem 32(1): 176188.

6. Xi J, Zhu X, Feng Y, Huang N, Luo G, et al. (2013) A novel class of tubulin inhibitors with promising anticancer activities. Molecular Cancer Research.

\begin{tabular}{|l|}
\hline \multicolumn{1}{|c|}{$\begin{array}{c}\text { Your next submission with Juniper Publishers } \\
\text { wou the below assets }\end{array}$} \\
- Quality Editorial service \\
- Swift Peer Review \\
- Reprints availability \\
- E-prints Service \\
- Manuscript Podcast for convenient understanding \\
- Global attainment for your research \\
- Manuscript accessibility in different formats \\
( Pdf, E-pub, Full Text, Audio) \\
- Unceasing customer service \\
Track the below URL for one-step submission \\
https://juniperpublishers.com/online-submission.php \\
\hline
\end{tabular}

